\title{
Association of methylenetetrahydrofolate reductase C677T polymorphism and serum lipid levels in the Guangxi Bai Ku Yao and Han populations
}

\author{
Lin Zhang ${ }^{1}$, Rui-Xing Yin ${ }^{1 *}$, Wan-Ying Liu', Lin Miao ${ }^{1}$, Dong-Feng Wu'', Lynn Htet Htet Aung ${ }^{1}$, Xi-Jiang Hu', \\ Xiao-Li Cao ${ }^{1}$, Jin-Zhen Wu' ${ }^{1}$, Shang-Ling Pan ${ }^{2}$
}

\begin{abstract}
Background: The association of methylenetetrahydrofolate reductase (MTHFR) gene polymorphism and serum lipid profiles is still controversial in diverse ethnics. Bai Ku Yao is an isolated subgroup of the Yao minority in China. The aim of the present study was to eveluate the association of MTHFR C677T polymorphism and several environmental factors with serum lipid levels in the Guangxi Bai Ku Yao and Han populations.

Methods: A total of 780 subjects of Bai Ku Yao and 686 participants of Han Chinese were randomly selected from our previous stratified randomized cluster samples. Genotyping of the MTHFR C677T was performed by polymerase chain reaction and restriction fragment length polymorphism combined with gel electrophoresis, and then confirmed by direct sequencing.

Results: The levels of serum total cholesterol (TC), high-density lipoprotein cholesterol (HDL-C), low-density lipoprotein cholesterol (LDL-C), apolipoprotein (Apo) Al and ApoB were lower in Bai Ku Yao than in Han $(P<0.05-0.001)$. The frequency of $C$ and $T$ alleles was $77.4 \%$ and $22.6 \%$ in Bai Ku Yao, and $60.9 \%$ and $39.1 \%$ in Han $(P<0.001)$; respectively. The frequency of CC, $C T$ and $T$ genotypes was $58.7 \%, 37.3 \%$ and $4.0 \%$ in Bai Ku Yao, and $32.6 \%, 56.4 \%$ and $11.0 \%$ in Han $(P<0.001)$; respectively. The levels of TC and LDL-C in both ethnic groups were significant differences among the three genotypes $(P<0.05-0.01)$. The $T$ allele carriers had higher serum TC and LDL-C levels than the $T$ allele noncarriers. The levels of ApoB in Han were significant differences among the three genotypes $(P<0.05)$. The $T$ allele carriers had higher serum ApoB levels as compared with the $T$ allele noncarriers. The levels of TC, TG and LDL-C in Bai Ku Yao were correlated with genotypes $(P<0.05-0.001)$, whereas the levels of LDL-C in Han were associated with genotypes $(P<0.001)$. Serum lipid parameters were also correlated with sex, age, body mass index, alcohol consumption, cigarette smoking, and blood pressure in the both ethnic groups.
\end{abstract}

Conclusions: The differences in serum TC, TG, LDL-C and ApoB levels between the two ethnic groups might partly result from different genotypic and allelic frequencies of the MTHFR C677T or different MTHFR gene-enviromental interactions.

\section{Introduction}

Disorders of lipid metabolism such as elevated serum levels of total cholesterol (TC) [1], triglyceride (TG) [2], low-density lipoprotein cholesterol (LDL-C) [3], and apolipoprotein (Apo) B [4], or low levels of high-density lipoprotein cholesterol (HDL-C) and ApoAI [4-6] have been

\footnotetext{
* Correspondence: yinruixing@yahoo.com.cn

'Department of Cardiology, Institute of Cardiovascular Diseases, the First Affiliated Hospital, Guangxi Medical University, 22 Shuangyong Road,

Nanning 530021, Guangxi, China

Full list of author information is available at the end of the article
}

considered to be important risk factors in the pathogenesis of atherosclerosis and coronary artery disease (CAD). It is well recognized that dyslipidemia is a complex trait caused by multiple environmental and genetic factors and their interactions [7-12]. Family history and twin studies have shown that genetic polymorphism could account for $40-60 \%$ of the interindividual variation in plasma lipid phenotypes [13-15]. The 5-10-methylenetetrahydrofolate reductase (MTHFR) gene that plays a role

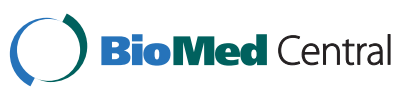

(c) 2010 Zhang et al; licensee BioMed Central Ltd. This is an Open Access article distributed under the terms of the Creative Commons Attribution License (http://creativecommons.org/licenses/by/2.0), which permits unrestricted use, distribution, and reproduction in any medium, provided the original work is properly cited. 
in vascular homeostasis has been considered to be good candidate for susceptibility to dyslipidemia.

The C677T polymorphism in the MTHFR gene, which encodes an enzyme involved in remethylation of homocysteine to methionine, leads to increased thermolability and impaired enzymatic activity. In its homozygous form, this variant possesses a reduced overall enzyme activity to less than $30 \%$ of normal, resulting on increased serum homocysteine levels $[16,17]$. The MTHFR 677T allele has been found to be associated with modifications of serum lipid concentrations [18-26] and the risk of CAD [26-30] in some studies but not in others [31-36].

Han is the largest ethnic group and Yao is the eleventh largest minority among the 55 minority groups in China according to the population size. Bai Ku Yao (White-trouser Yao), an isolated subgroup of the Yao minority, is named so because all the men wear white knee-length knickerbockers. The population size is about 30000 . Because of isolation from the other ethnic groups, the special customs and cultures including their clothing, intra-ethnic marriages, dietary habits, and corn wine and rum intakes are still completely preserved to the present day. In previous epidemiological studies, we found that serum lipid levels were lower in Bai Ku Yao than in Han Chinese from the same village $[7,8]$. This ethnic difference in serum lipid profiles is still not well known. We hypothesized that there may be significant differences in some genetic factors between the two ethnic groups. Therefore, the aim of the present study was to detect the association of MTHFR C677T polymorphism and several environmental factors with serum lipid levels in the Guangxi Bai Ku Yao and Han populations.

\section{Materials and methods \\ Study population}

A total of 780 subjects of Bai Ku Yao who reside in Lihu and Baxu villages in Nandan County, Guangxi Zhuang Autonomous Region, People's Republic of China were randomly selected from our previous stratified randomized cluster samples $[7,8]$. The ages of the subjects ranged from 15 to 80 years, with an average age of $40.24 \pm 13.07$ years. There were 381 males $(48.85 \%)$ and 399 females $(51.15 \%)$. All subjects were rural agricultural workers. The subjects accounted for $2.60 \%$ of total Bai $\mathrm{Ku}$ Yao population. During the same period, a total of 686 people of Han Chinese who reside in the same villages were also randomly selected from our previous stratified randomized cluster samples $[7,8]$. The average age of the subjects was $39.61 \pm 14.67$ years (range 15 to $80)$. There were 342 men $(49.85 \%)$ and 344 women $(50.15 \%)$. All of them were also rural agricultural workers. All study subjects were essentially healthy and had no evidence of any chronic illness, including hepatic, renal, or thyroid. The participants with a history of heart attack or myocardial infarction, stroke, congestive heart failure, diabetes or fasting blood glucose $\geq 7.0$ $\mathrm{mmol} / \mathrm{L}$ determined by glucose meter have been excluded. The participants were not taking medications known to affect serum lipid levels (lipid-lowering drugs such as statins or fibrates, beta-blockers, diuretics, or hormones). The present study was approved by the Ethics Committee of the First Affiliated Hospital, Guangxi Medical University. Informed consent was obtained from all subjects after they received a full explanation of the study.

\section{Epidemiological survey}

The survey was carried out using internationally standardized methods, following a common protocol [37]. Information on demographics, socioeconomic status, and lifestyle factors was collected with standardized questionnaires. The alcohol information included questions about the number of liangs (about $50 \mathrm{~g}$ ) of rice wine, corn wine, rum, beer, or liquor consumed during the preceding 12 months. Alcohol consumption was categorized into groups of grams of alcohol per day: < 25 and $\geq 25$. Smoking status was categorized into groups of cigarettes per day: $<20$ and $\geq 20$. At the physical examination, several anthropometric parameters, such as height, weight, and waist circumference were measured. Sitting blood pressure was measured three times with the use of a mercury sphygmomanometer after the subjects had a 5-minute rest, and the average of the three measurements was used for the level of blood pressure. Systolic blood pressure was determined by the first Korotkoff sound, and diastolic blood pressure by the fifth Korotkoff sound. Body weight, to the nearest 50 grams, was measured using a portable balance scale. Subjects were weighed without shoes and in a minimum of clothing. Height was measured, to the nearest $0.5 \mathrm{~cm}$, using a portable steel measuring device. From these two measurements body mass index (BMI, $\mathrm{kg} / \mathrm{m}^{2}$ ) was calculated. Waist circumference was measured with a nonstretchable measuring tape, at the level of the smallest area of the waist, to the nearest $0.1 \mathrm{~cm}$.

\section{Biochemical analysis}

A venous blood sample of $8 \mathrm{ml}$ was obtained from all subjects between 8 and $11 \mathrm{AM}$, after at least 12 hours of fasting, from a forearm vein after venous occlusion for few seconds in a sitting position. A part of the sample $(3 \mathrm{ml})$ was collected into glass tubes and allowed to clot at room temperature, and used to determine serum lipid levels. Another part of the sample $(5 \mathrm{ml})$ was transferred to tubes with anticoagulate solution $(4.80 \mathrm{~g} / \mathrm{L}$ citric acid, $14.70 \mathrm{~g} / \mathrm{L}$ glucose, and $13.20 \mathrm{~g} / \mathrm{L}$ tri-sodium citrate) and used to extract DNA. Immediately following 
clotting serum was separated by centrifugation for 15 minutes at $3000 \mathrm{rpm}$. The levels of TC, TG, HDL-C, and LDL-C in samples were determined by enzymatic methods with commercially available kits, Tcho-1, TGLH (RANDOX Laboratories Ltd., Ardmore, Diamond Road, Crumlin Co. Antrim, United Kingdom, BT29 4QY), Cholestest N HDL, and Cholestest LDL (Daiichi Pure Chemicals Co., Ltd., Tokyo, Japan); respectively. Serum ApoAI and ApoB levels were detected by the immunoturbidimetric immunoassay using a commercial kit (RANDOX Laboratories Ltd.). All determinations were performed with an autoanalyzer (Type 7170A; Hitachi Ltd., Tokyo, Japan) in the Clinical Science Experiment Center of the First Affiliated Hospital, Guangxi Medical University $[7,8]$.

\section{DNA amplification and genotyping}

Genomic DNA was isolated from peripheral blood leukocytes using the phenol-chloroform method [11,12]. The extracted DNA was stored at $4^{\circ} \mathrm{C}$ until analysis. Genotyping of the MTHFR C677T was performed by polymerase chain reaction and restriction fragment length polymorphism (PCR-RFLP) [38-40]. PCR amplification was performed using 5'-CAAAGGCCACCCCGAAGC-3' and 5'-AGGACGGTGCGGTGAGAGTG-3' (Sangon, Shanghai, People's Republic of China) as the forward and reverse primer pairs; respectively. Each amplification reaction was performed in a total volume of $25 \mu \mathrm{L}$, containing $10 \times$ PCR buffer $\left(1.8 \mathrm{mM} \mathrm{MgCl}_{2}\right)$ $2.5 \mu \mathrm{L}, 1 \mathrm{U}$ Taq polymerase, $2.5 \mathrm{mmol} / \mathrm{L}$ of each dNTP (Tiangen, Beijing, People's Republic of China) $2.0 \mu \mathrm{L}, 5$ $\mathrm{pmol} / \mathrm{L}$ of each primer $(0.5 \mu \mathrm{L})$ and $2 \mu \mathrm{L}$ of genomic DNA, processing started with $94^{\circ} \mathrm{C}$ for 5 min and 34 cycles at $94^{\circ} \mathrm{C}$ for $45 \mathrm{~s}, 61.5^{\circ} \mathrm{C}$ for $40 \mathrm{~s}$ and $72^{\circ} \mathrm{C}$ for 50 s. This was followed by a final extension at $72^{\circ} \mathrm{C}$ for 7 min. Then $5 \mathrm{U}$ of $\operatorname{Hinfl}$ enzyme was added directly to the PCR products $(5 \mu \mathrm{L})$ and digested at $37^{\circ} \mathrm{C}$ overnight. After restriction enzyme digestion of the amplified DNA, genotypes were identified by electrophoresis on $2 \%$ agarose gels and visualized with ethidium-bromide staining ultraviolet illumination. Genotypes were scored by an experienced reader blinded to epidemiological data and serum lipid levels. Six samples (CC, CT and TT genotypes in two; respectively) detected by the PCRRFLP were also confirmed by direct sequencing. The PCR products were purified by low melting point gel electrophoresis and phenol extraction, and then the DNA sequences were analyzed in Shanghai Sangon Biological Engineering Technology \& Services Co., Ltd., People's Republic of China.

\section{Diagnostic criteria}

The normal values of serum TC, TG, HDL-C, LDL-C, ApoAI, ApoB levels, and the ratio of ApoAI to ApoB in our Clinical Science Experiment Center were 3.10-5.17, $0.56-1.70,0.91-1.81,2.70-3.20 \mathrm{mmol} / \mathrm{L}, 1.00-1.78,0.63-$ $1.14 \mathrm{~g} / \mathrm{L}$, and 1.00-2.50; respectively. The individuals with $\mathrm{TC}>5.17 \mathrm{mmol} / \mathrm{L}$ and/or TG $>1.70 \mathrm{mmol} / \mathrm{L}$ were defined as hyperlipidemic $[7,8]$. Hypertension was diagnosed according to the criteria of 1999 World Health Organization-International Society of Hypertension Guidelines for the management of hypertension [41,42]. The diagnostic criteria of overweight and obesity were according to the Cooperative Meta-analysis Group of China Obesity Task Force. Normal weight, overweight and obesity were defined as a BMI $<24,24-28$, and $>$ $28 \mathrm{~kg} / \mathrm{m}^{2}$; respectively [43].

\section{Statistical analyses}

Epidemiological data were recorded on a pre-designed form and managed with Excel software. All statistical analyses were done with the statistical software package SPSS 13.0 (SPSS Inc., Chicago, Illinois). Quantitative variables were expressed as mean \pm standard deviation (serum TG levels were presented as medians and interquartile ranges). Qualitative variables were expressed as percentages. Allele frequency was determined via direct counting, and the standard goodness-of-fit test was used to test the Hardy-Weinberg equilibrium. Difference in genotype distribution between the groups was obtained using the chi-square test. The difference in general characteristics between Bai Ku Yao and Han was tested by the Student's unpaired $t$-test. The association of genotypes and serum lipid parameters was tested by analysis of covariance (ANCOVA). Sex, age, BMI, blood pressure, alcohol consumption, cigarette smoking were adjusted for the statistical analysis. In order to evaluate the association of serum lipid levels with genotypes and several environment factors, multivariate logistic regression analysis was also performed in the combined population of Bai Ku Yao and Han, Bai Ku Yao, and Han; respectively. A $P$ value of less than 0.05 was considered statistically significant.

\section{Results}

\section{General characteristics and serum lipid levels}

Table 1 gives the general characteristics and serum lipid levels between the Bai Ku Yao and Han populations. The levels of BMI, systolic blood pressure, diastolic blood pressure, pulse pressure, serum TC, HDL-C, LDL-C, ApoAI and ApoB were lower in Bai Ku Yao than in Han Chinese $(P<0.05-0.001)$, whereas the percentage of subjects who smoked cigarettes was higher in Bai Ku Yao than in Han $(P<0.001)$. There were no significant differences in the levels of serum TG, the ratio of ApoAI to ApoB, age structure, the percentages of subjects who consumed alcohol, or the ratio of male to female between the two ethnic groups $(P>0.05$ for all). 
Table 1 The general characteristics and serum lipid levels between the Bai Ku Yao and Han populations

\begin{tabular}{|c|c|c|c|c|}
\hline Parameter & Bai Ku Yao & Han Chinese & $t\left(\chi^{2}\right)$ & $P$ \\
\hline Number & 780 & 686 & - & - \\
\hline Male/female & $381 / 399$ & $342 / 344$ & 0.148 & 0.714 \\
\hline Age (years) & $40.24 \pm 13.07$ & $39.61 \pm 14.67$ & 0.866 & 0.386 \\
\hline Body mass index $\left(\mathrm{kg} / \mathrm{m}^{2}\right)$ & $22.05 \pm 2.31$ & $22.51 \pm 2.74$ & -3.467 & 0.001 \\
\hline Systolic blood pressure (mmHg) & $116.55 \pm 15.39$ & $120.63 \pm 15.94$ & -4.985 & 0.000 \\
\hline Diastolic blood pressure $(\mathrm{mmHg})$ & $74.78 \pm 9.30$ & $76.29 \pm 10.04$ & -2.983 & 0.003 \\
\hline Pulse pressure $(\mathrm{mmHg})$ & $41.77 \pm 11.44$ & $44.40 \pm 10.94$ & -4.478 & 0.000 \\
\hline \multicolumn{5}{|l|}{ Cigarette smoking [n(\%)] } \\
\hline Nonsmoker & $531(68.1)$ & $514(74.9)$ & & \\
\hline$<20$ cigarettes/day & 128(16.4) & $52(7.6)$ & & \\
\hline$\geq 20$ cigarettes/day & $121(15.5)$ & $120(17.5)$ & 26.451 & 0.000 \\
\hline \multicolumn{5}{|l|}{ Alcohol consumption [n(\%)] } \\
\hline Nondrinker & $443(56.8)$ & $401(58.4)$ & & \\
\hline$<25$ g/day & 240(30.8) & 179(26.1) & & \\
\hline$\geq 25$ g/day & 107(13.4) & $106(15.5)$ & 3.666 & 0.160 \\
\hline Total cholesterol (mmol/L) & $4.26 \pm 0.93$ & $4.72 \pm 0.93$ & -9.372 & 0.000 \\
\hline Triglyceride (mmol/L) & $0.97(0.71)$ & $1.01(0.77)$ & -1.670 & 0.095 \\
\hline $\mathrm{HDL}-\mathrm{C}(\mathrm{mmol} / \mathrm{L})$ & $1.65 \pm 0.75$ & $1.92 \pm 0.50$ & -11.272 & 0.000 \\
\hline LDL-C (mmol/L) & $2.50 \pm 0.75$ & $2.59 \pm 0.72$ & -2.350 & 0.019 \\
\hline Apolipoprotein (Apo) Al (g/L) & $1.29 \pm 0.32$ & $1.42 \pm 0.23$ & -8.732 & 0.000 \\
\hline ApoB $(g / L)$ & $0.83 \pm 0.23$ & $0.90 \pm 0.21$ & -6.656 & 0.000 \\
\hline ApoAl/ApoB & $1.69 \pm 0.78$ & $1.64 \pm 0.43$ & 1.703 & 0.089 \\
\hline
\end{tabular}

HDL-C, high-density lipoprotein cholesterol; LDL-C, low-density lipoprotein cholesterol. The value of TG was presented as median (interquartile range). The difference between the two ethnic groups was determined by the Wilcoxon-Mann-Whitney test.

\section{Results of electrophoresis and genotyping}

After the genomic DNA of the samples was amplified by PCR and imaged by $2 \%$ agarose gel electrophoresis, the purpose gene of $254 \mathrm{bp}$ nucleotide sequences could be found in all samples (Figure 1). The genotypes identified were named according to the presence or absence of the enzyme restriction sites, when a $\mathrm{C}$ to $\mathrm{T}$ transversion at nucleotide position 677 of the MTHFR gene. The presence of the cutting site indicates the $\mathrm{T}$ allele, while its absence indicates the $\mathrm{C}$ allele. Thus, the $\mathrm{CC}$ genotype is homozygote for the absence of the site (band at $254 \mathrm{bp}$ ), CT genotype is heterozygote for the absence and presence of the site (bands at 254-, 173- and 72-bp), and TT genotype is homozygote for the presence of the site (bands at 173- and 72- bp; Figure 2).

\section{Genotypic and allelic frequencies}

The frequency of MTHFR C677T alleles and genotypes is shown in Table 2. The frequency of $\mathrm{C}$ and $\mathrm{T}$ alleles was $77.4 \%$ and $22.6 \%$ in Bai $\mathrm{Ku}$ Yao, and $60.9 \%$ and $39.1 \%$ in Han $(P<0.001)$; respectively. The frequency of $\mathrm{CC}, \mathrm{CT}$ and TT genotypes was $58.7 \%, 37.3 \%$ and $4.0 \%$ in Bai Ku Yao, and $32.6 \%, 56.4 \%$ and $11.0 \%$ in Han $(P<$ $0.001)$; respectively. There was no significant difference in the genotypic and allelic frequencies between males and females in both ethnic groups.

\section{Results of sequencing}

The results were shown as CC, CT and TT genotypes by PCR-RFLP, the CC, CT and TT genotypes were also confirmed by sequencing (Figure 3); respectively.

\section{Genotypes and serum lipid levels}

As shown in Table 3, the levels of TC and LDL-C were significant differences among the three genotypes in both ethnic groups $(P<0.05-0.01)$. The T allele carriers had higher serum TC and LDL-C levels than the T allele noncarriers. The levels of ApoB were also significant differences among the three genotypes in Han Chinese $(P<0.05)$. The $\mathrm{T}$ allele carriers had higher serum ApoB levels than the $\mathrm{T}$ allele noncarriers. There was no significant difference in the levels of TG, HDL-C, ApoAI and the ratio of ApoAI to ApoB among the three genotypes in both ethnic groups $(P>0.05$ for all).

\section{Relative factors for serum lipid parameters}

Multivariate logistic regression analysis showed that the levels of TC, TG and LDL-C were correlated with genotypes in Bai Ku Yao $(P<0.05-0.001)$, whereas the levels of LDL-C were correlated with genotypes in $\operatorname{Han}(P<$ 0.001). Serum lipid parameters were also correlated with sex, age, BMI, alcohol consumption, cigarette smoking, and blood pressure in both ethnic groups (Table 4). 


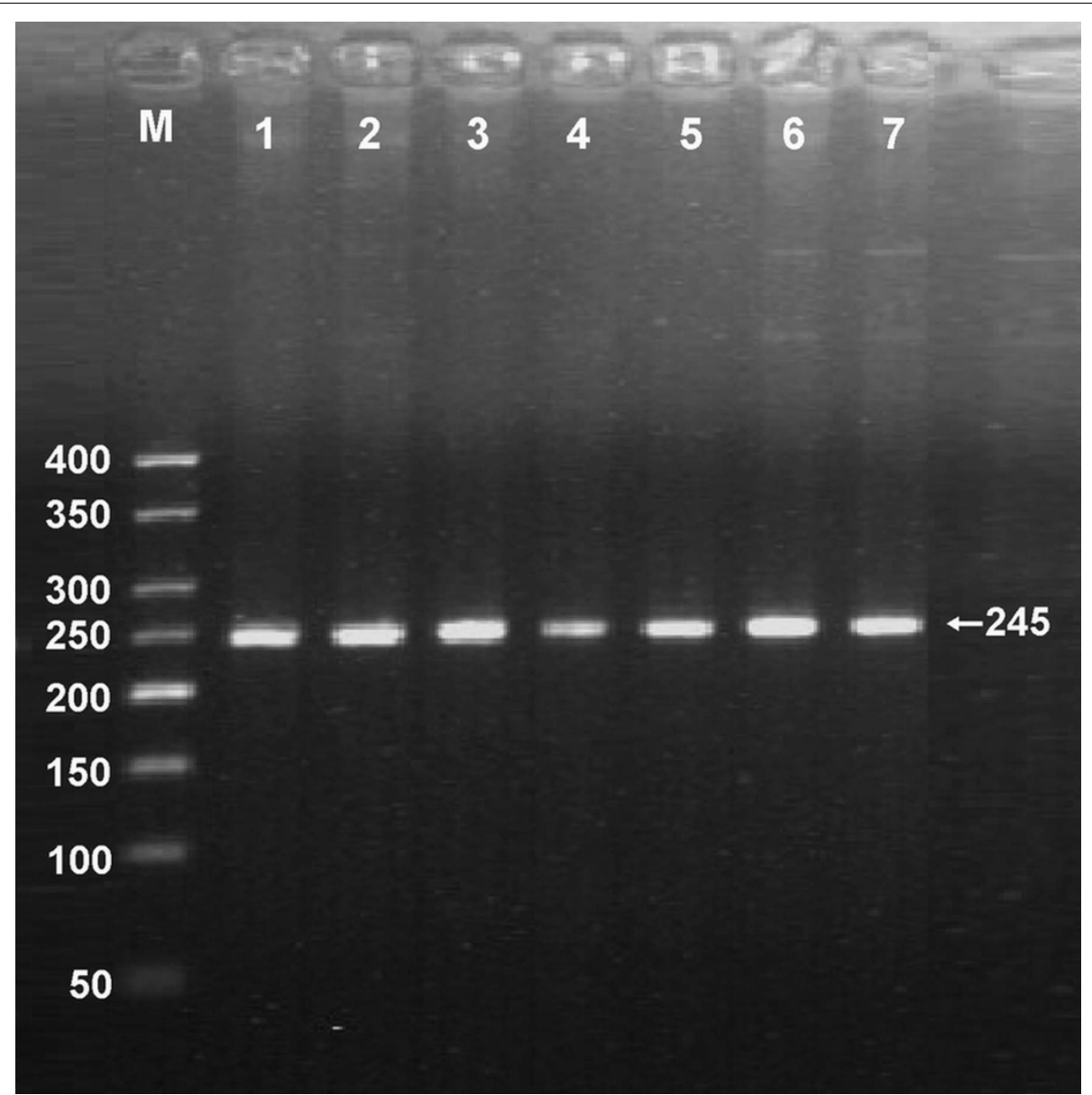

Figure 1 Electrophoresis of PCR products of the samples. Lane M, 50 bp marker ladder; lanes 1-7, samples. The 245 bp bands are the target genes.

\section{Discussion}

The present study shows that the levels of serum TC, HDL-C, LDL-C, ApoAI and ApoB were lower in Bai Ku Yao than in Han. There was no significant difference in the serum levels of TG and the ratio of ApoAI to ApoB between the two ethnic groups. These findings are consistent with those of our previous studies in a large population [7]. It is well known that dyslipidemia is a multifactorial origin, including hereditary and acquired risk factors. Bai $\mathrm{Ku}$ Yao is an isolated subgroup of the Yao minority in China. Strict intra-ethnic marriages have been performed in this population from time immemorial. Therefore, we hypothesized that the hereditary characteristics and genotypes of some lipid metabolism-related genes in this population may be different from those in Han Chinese.

The prevalence of the T677T genotype varies among different ethnic groups. It is very low in African populations, whereas in Europe and North America it ranges between $5 \%$ and $15 \%$. In Italy an even higher prevalence has been reported in some regions [44]. The frequency of the MTHFR 677T allele in healthy controls was 13.4\% among Saudi Arabian [45], 21.67\% among Egjiptian [36], 28.75\% among Tunisian Arabs [26], 35.02\% among the Greek (Attica region, the ATTICA study) [20], 47.9\% (Ashkenazi Jews) and 18.1\% (Yemenite Jews) among Israeli [46]. MTHFR 677T variant was detected in only $20 \%$ of Black South Africans (no homozygotes) versus $56 \%$ of Caucasians with $12 \%$ homozygotes $(P<$ 0.0001 ) [31]. It has been reported that the homozygocity for the $\mathrm{T}$ allele of MTHFR was more frequent in patients with premature myocardial infarction than in controls $(27.1 \%$ vs. $14.6 \%, P=0.02)$ [30], in CAD patients than in control subjects $(28.5 \%$ vs. $13.5 \%, P<$ 0.00003 ) [27], and in diabetics than in healthy subjects $(12.8 \%$ vs. $7.2 \%)$ [23]. However, there was no significant difference in genotypic or allelic frequencies of the MTHFR C677T between hemodialysis patients and healthy controls [36], between hyperlipidemic and control groups [24], and between carotid stenosis patients 


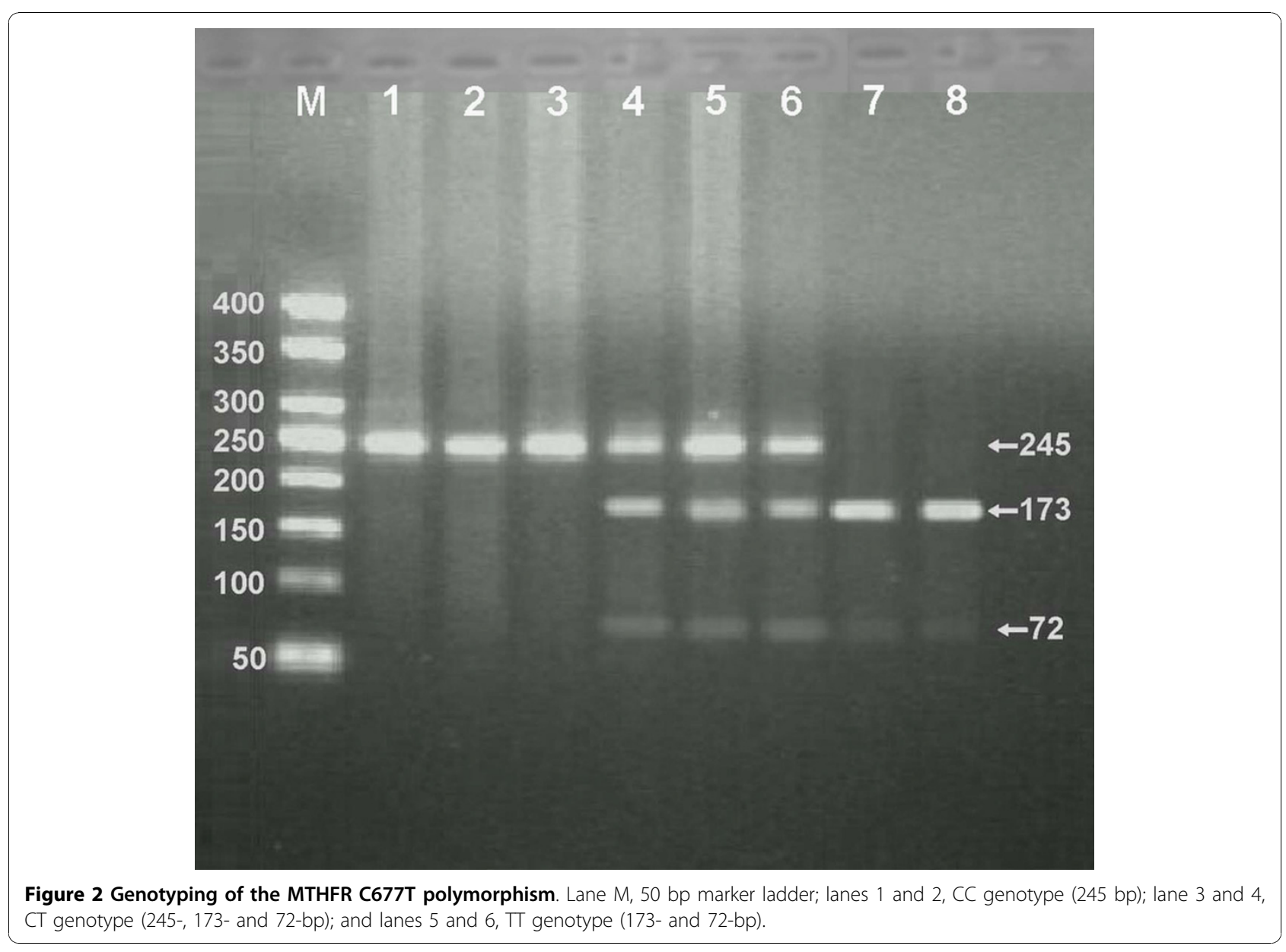

Table 2 Genotypic and allelic frequencies of the MTHFR C677T between the Bai Ku Yao and Han populations [n (\%)]

\begin{tabular}{|c|c|c|c|c|c|c|}
\hline \multirow[t]{2}{*}{ Group } & \multirow[t]{2}{*}{$\mathrm{n}$} & \multicolumn{3}{|c|}{ Genotype } & \multicolumn{2}{|c|}{ Allele } \\
\hline & & CC & CT & $T T$ & $C$ & $\mathrm{~T}$ \\
\hline Bai Ku Yao & 780 & $458(58.7)$ & $291(37.3)$ & $31(4.0)$ & $1207(77.4)$ & $353(22.6)$ \\
\hline Han Chinese & 686 & $224(32.6)$ & $387(56.4)$ & $75(11.0)$ & $835(60.9)$ & $537(39.1)$ \\
\hline$\chi^{2}$ & - & & 106.6 & & 94. & \\
\hline$P$ & - & & 0.000 & & 0.0 & \\
\hline \multicolumn{7}{|l|}{ Bai Ku Yao } \\
\hline Male & 381 & $228(59.8)$ & $131(34.4)$ & $22(5.8)$ & $587(77.0)$ & $175(23.0)$ \\
\hline Female & 399 & 230(57.6) & 156(39.1) & 13(3.3) & $616(77.2)$ & $182(22.8)$ \\
\hline$\chi^{2}$ & - & & 4.088 & & 0.0 & \\
\hline$P$ & - & & 0.130 & & 0.9 & \\
\hline \multicolumn{7}{|l|}{ Han Chinese } \\
\hline Male & 342 & 107(31.3) & 199(58.2) & $36(10.5)$ & $413(60.4)$ & 271(39.6) \\
\hline Female & 344 & $117(34.0)$ & 188(54.7) & 39(11.3) & $422(61.3)$ & $266(38.7)$ \\
\hline$\chi^{2}$ & - & & 0.873 & & 0.7 & \\
\hline$P$ & - & & 0.928 & & 0.7 & \\
\hline
\end{tabular}

and control subjects [22]. In the present study, we showed that the frequency of MTHFR 677T allele was lower in Bai Ku Yao than in Han. The frequency of CT and TT genotypes was also lower in Bai Ku Yao than in Han. These results indicate that the allelic variation of the MTHFR C677T may have an ethnic specificity.

The association of MTHFR C677T polymorphism and plasma or serum lipid profiles in different populations has been evaluated in several studies. However, the results are inconsistent. The MTHFR 677T allele has been found to be associated with unfavorable serum lipid profiles [18-26] and increased risk of CAD in some studies [26-30] but not in others [31-36]. It has been reported that the subjects with the $\mathrm{T}$ allele had the highest levels of TC and LDL-C, and the subjects with the CC genotype had the lowest [19]. Pitsavos et al. found that the oxidized (ox)-LDL levels were higher in TT genotype as compared to $\mathrm{CC}$ and $\mathrm{CT}$ genotypes. Mediterranean diet was associated with lower ox-LDL levels in TT and CT individuals, but not in CC subjects, 

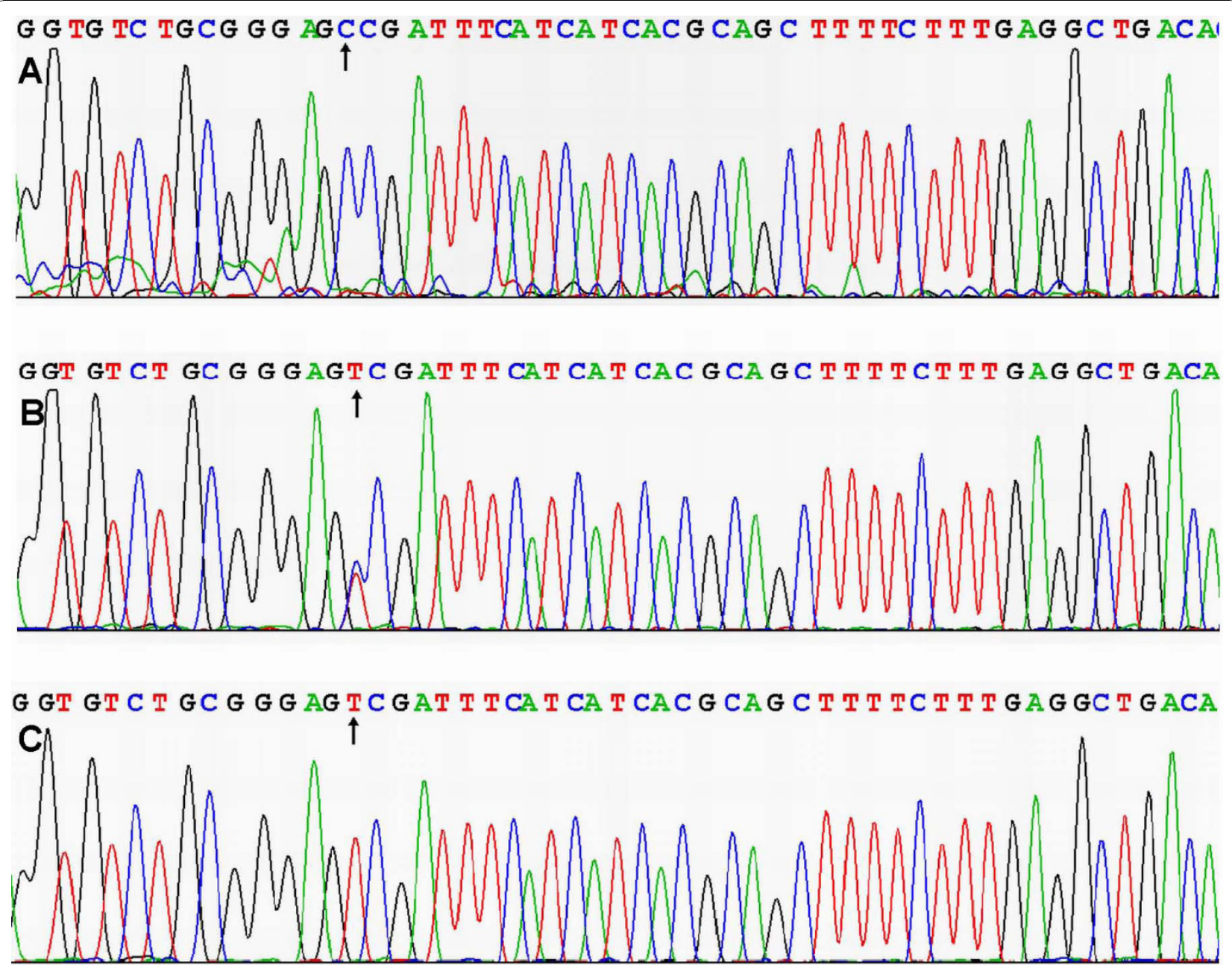

Figure 3 A part of the nucleotide sequence of the MTHFR C677T locus. (A) CC genotype; (B) CT genotype; (C) TT genotype.

after controlling for several potential confounders [20]. CAD patients with the MTHFR TT genotype had higher cholesterol and TG concentrations than patients with the MTHFR CC genotype [26]. TC and TG levels were statistically different in all MTHFR genotypes and in TC/TT groups [22]. The hyperlipidemia patients with MTHFR CT/TT genotype had a higher concentration of TG than those with CC genotype [24]. Real et al. [25] found significant differences in plasma HDL-C (CC: 1.39 \pm 0.34, CT: $1.33 \pm 0.39$ and TT: $1.14 \pm 0.26 \mathrm{mmol} / \mathrm{L}, P$ $=0.028$ ) between the C677T MTHFR genotypes, that were also found when sex, age, and BMI were included as covariables. A significant correlation was also found between plasma homocysteine values and plasma HDL$\mathrm{C}$, but no correlations were found with age, BMI or other lipid and ApoB plasma values. However, Spiridonova et al. [33] showed that the MTHFR gene polymorphism was not associated with variation in either $\mathrm{TC}$, very-low-density-lipoprotein cholesterol (VLDL),
LDL-C, HDL-C, or TG levels in CAD patients and control subjects. Homocysteine did not correlate with TC, LDL, HDL, VLDL and TG in obese children and adolescents [32]. In the present study, we found that the levels of TC and LDL-C were significant differences among the three genotypes in both Bai Ku Yao and Han populations, the $\mathrm{T}$ allele carriers had higher serum $\mathrm{TC}$ and LDL-C levels as compared with the T allele noncarriers. The levels of ApoB in Han were also significant differences among the three genotypes, the $T$ allele carriers had higher serum ApoB levels than the $\mathrm{T}$ allele noncarriers. Multivariate logistic regression analysis showed that the levels of TC, TG and LDL-C in Bai Ku Yao and LDL-C in Han were correlated with genotypes. These data suggest that the MTHFR C677T polymorphism was mainly associated with serum TC and LDL-C levels in our study populations, and might also involve in serum TG levels in Bai Ku Yao, and serum ApoB levels in Han. The reason for this discrepancy between the 
Table 3 Genotypic frequencies of the MTHFR C677T and serum lipid levels between the Bai Ku Yao and Han populations

\begin{tabular}{|c|c|c|c|c|c|c|c|c|}
\hline Genotype & $\mathbf{n}$ & $\mathrm{TC}(\mathrm{mmol} / \mathrm{L})$ & $\mathrm{TG}(\mathrm{mmol} / \mathrm{L})$ & HDL-C (mmol/L) & LDL-C (mmol/L) & ApoAl (g/L) & ApoB (g/L) & ApoAl/ApoB \\
\hline \multicolumn{9}{|l|}{ Bai Ku Yao } \\
\hline CC & 458 & $4.20 \pm 0.85$ & $0.97(0.73)$ & $1.62 \pm 0.40$ & $2.45 \pm 0.70$ & $1.27 \pm 3.15$ & $0.82 \pm 0.22$ & $1.69 \pm 0.81$ \\
\hline$C T$ & 291 & $4.33 \pm 1.06$ & $0.94(0.68)$ & $1.67 \pm 0.44$ & $2.57 \pm 0.85^{\mathrm{a}}$ & $1.30 \pm 3.33$ & $0.84 \pm 0.25$ & $1.70 \pm 0.77$ \\
\hline$\pi$ & 31 & $4.52 \pm 0.62$ & $1.11(0.68)$ & $1.75 \pm 0.40$ & $2.67 \pm 0.44^{a}$ & $1.38 \pm 0.34$ & $0.86 \pm 0.15$ & $1.63 \pm 0.40$ \\
\hline$F$ & - & 2.807 & 0.932 & 1.993 & 3.299 & 1.884 & 0.592 & 0.091 \\
\hline$P$ & - & 0.061 & 0.334 & 0.137 & 0.037 & 0.153 & 0.554 & 0.913 \\
\hline CC & 458 & $4.20 \pm 0.85$ & $0.97(0.73)$ & $1.62 \pm 0.40$ & $2.45 \pm 0.70$ & $1.27 \pm 0.31$ & $0.82 \pm 0.22$ & $1.69 \pm 0.81$ \\
\hline $\mathrm{CT} / \mathrm{TT}$ & 322 & $4.34 \pm 1.02$ & $0.96(0.68)$ & $1.68 \pm 0.43$ & $2.58 \pm 0.81$ & $1.31 \pm 0.33$ & $0.84 \pm 0.24$ & $1.69 \pm 0.75$ \\
\hline$F$ & - & 2.098 & 0.611 & 1.722 & 2.462 & 1.489 & 0.942 & 0.040 \\
\hline$P$ & - & 0.036 & 0.541 & 0.085 & 0.014 & 0.137 & 0.347 & 0.968 \\
\hline \multicolumn{9}{|l|}{ Male } \\
\hline CC & 228 & $4.20 \pm 0.90$ & $1.08(0.78)$ & $1.64 \pm 0.45$ & $2.38 \pm 0.75$ & $1.32 \pm 0.34$ & $0.81 \pm 0.22$ & $1.82 \pm 1.01$ \\
\hline$C T$ & 131 & $4.33 \pm 1.27$ & $1.11(0.80)$ & $1.67 \pm 0.50$ & $2.54 \pm 1.01$ & $1.34 \pm 0.40$ & $0.81 \pm 0.26$ & $1.87 \pm 1.03$ \\
\hline$\pi$ & 22 & $4.63 \pm 0.73$ & $1.02(0.66)$ & $1.80 \pm 0.39$ & $2.75 \pm 0.54$ & $1.37 \pm 0.40$ & $0.88 \pm 0.18$ & $1.61 \pm 0.44$ \\
\hline$F$ & - & 2.076 & 1.005 & 1.416 & 2.873 & 0.258 & 0.971 & 0.636 \\
\hline$P$ & - & 0.127 & 0.605 & 0.244 & 0.058 & 0.773 & 0.379 & 0.530 \\
\hline CC & 228 & $4.20 \pm 0.90$ & 1.08(0.78) & $1.64 \pm 0.45$ & $2.38 \pm 0.75$ & $1.32 \pm 0.34$ & $0.81 \pm 0.22$ & $1.82 \pm 1.01$ \\
\hline $\mathrm{CT} / \mathrm{TT}$ & 153 & $4.37 \pm 1.21$ & $1.07(0.80)$ & $1.69 \pm 0.48$ & $2.58 \pm 0.96$ & $1.35 \pm 0.39$ & $0.82 \pm 0.25$ & $1.83 \pm 0.97$ \\
\hline$F$ & - & 1.619 & 0.105 & 1.108 & 2.139 & 0.701 & 0.536 & 0.064 \\
\hline$P$ & - & 0.106 & 0.916 & 0.269 & 0.033 & 0.484 & 0.592 & 0.949 \\
\hline \multicolumn{9}{|c|}{ Female } \\
\hline CC & 230 & $4.21 \pm 0.80$ & $0.92(0.69)$ & $1.61 \pm 0.35$ & $2.51 \pm 0.63$ & $1.23 \pm 0.25$ & $0.83 \pm 0.20$ & $1.56 \pm 0.51$ \\
\hline$C T$ & 156 & $4.28 \pm 0.83$ & $0.82(0.65)$ & $1.67 \pm 0.39$ & $2.57 \pm 0.65$ & $1.27 \pm 0.25$ & $0.85 \pm 0.24$ & $1.50 \pm 0.38$ \\
\hline$\pi$ & 13 & $4.68 \pm 0.66$ & $1.65(0.95)^{\mathrm{ac}}$ & $1.63 \pm 0.34$ & $2.87 \pm 0.53$ & $1.36 \pm 0.29$ & $0.91 \pm 0.14$ & $1.57 \pm 0.42$ \\
\hline$F$ & - & 2.363 & 9.541 & 1.024 & 2.097 & 2.433 & 0.841 & 0.108 \\
\hline$P$ & - & 0.095 & 0.008 & 0.360 & 0.124 & 0.089 & 0.432 & 0.897 \\
\hline CC & 230 & $4.21 \pm 0.80$ & $0.92(0.69)$ & $1.61 \pm 0.35$ & $2.51 \pm 0.63$ & $1.23 \pm 0.25$ & $0.83 \pm 0.20$ & $1.56 \pm 0.51$ \\
\hline $\mathrm{CT} / \mathrm{TT}$ & 156 & $4.32 \pm 0.82$ & $0.83(0.66)$ & $1.66 \pm 0.38$ & $2.59 \pm 0.64$ & $1.28 \pm 0.26$ & $0.86 \pm 0.23$ & $1.56 \pm 0.42$ \\
\hline$F$ & - & 1.344 & 0.757 & 1.395 & 1.210 & 1.738 & 0.730 & 0.019 \\
\hline$P$ & - & 0.180 & 0.449 & 0.164 & 0.227 & 0.083 & 0.466 & 0.985 \\
\hline \multicolumn{9}{|c|}{ Han Chinese } \\
\hline CC & 224 & $4.56 \pm 0.81$ & $0.97(0.73)$ & $1.91 \pm 0.52$ & $2.48 \pm 0.66$ & $1.40 \pm 0.23$ & $0.88 \pm 0.20$ & $1.67 \pm 0.43$ \\
\hline$C T$ & 387 & $4.77 \pm 0.95^{\mathrm{a}}$ & $1.02(0.79)$ & $1.92 \pm 0.48$ & $2.64 \pm 0.73^{\mathrm{a}}$ & $1.42 \pm 0.23$ & $0.92 \pm 0.21$ & $1.61 \pm 0.41$ \\
\hline$\pi$ & 75 & $4.88 \pm 1.05^{b}$ & $1.02(0.78)$ & $1.93 \pm 0.53$ & $2.69 \pm 0.80^{\mathrm{a}}$ & $1.42 \pm 0.25$ & $0.92 \pm 0.23$ & $1.65 \pm 0.51$ \\
\hline$F$ & - & 5.003 & 2.468 & 0.093 & 4.218 & 0.508 & 2.756 & 1.214 \\
\hline$P$ & - & 0.007 & 0.288 & 0.911 & 0.015 & 0.602 & 0.064 & 0.298 \\
\hline $\mathrm{CC}$ & 224 & $4.56 \pm 0.81$ & $0.97(0.73)$ & $1.90 \pm 0.52$ & $2.48 \pm 0.66$ & $1.40 \pm 0.23$ & $0.88 \pm 0.20$ & $1.67 \pm 0.43$ \\
\hline $\mathrm{CT} / \mathrm{TT}$ & 462 & $4.79 \pm 0.97$ & $1.02(0.79)$ & $1.92 \pm 0.48$ & $2.65 \pm 0.74$ & $1.42 \pm 0.24$ & $0.92 \pm 0.21$ & $1.62 \pm 0.43$ \\
\hline$F$ & - & 3.036 & 1.538 & 0.347 & 2.853 & 1.007 & 2.346 & 1.399 \\
\hline$P$ & - & 0.002 & 0.124 & 0.708 & 0.004 & 0.314 & 0.019 & 0.162 \\
\hline \multicolumn{9}{|l|}{ Male } \\
\hline CC & 107 & $4.58 \pm 0.86$ & $1.03(0.73)$ & $188 \pm 0.57$ & $2.45 \pm 0.69$ & $1.39 \pm 0.26$ & $0.88 \pm 0.21$ & $1.66 \pm 0.46$ \\
\hline $\mathrm{CT}$ & 199 & $4.72 \pm 0.94$ & $1.02(0.80)$ & $1.85 \pm 0.49$ & $2.61 \pm 0.69$ & $1.40 \pm 0.24$ & $0.91 \pm 0.20$ & $1.60 \pm 0.41$ \\
\hline$\pi$ & 36 & $5.08 \pm 1.05^{\mathrm{bc}}$ & $1.06(0.80)$ & $1.93 \pm 0.54$ & $2.79 \pm 0.91^{\mathrm{a}}$ & $1.43 \pm 0.27$ & $0.94 \pm 0.24$ & $1.64 \pm 0.57$ \\
\hline$F$ & - & 4.105 & 0.554 & 0.328 & 3.426 & 0.461 & 0.991 & 0.612 \\
\hline$P$ & - & 0.017 & 0.758 & 0.720 & 0.034 & 0.631 & 0.372 & 0.543 \\
\hline CC & 107 & $4.58 \pm 0.86$ & $1.03(0.73)$ & $188 \pm 0.57$ & $2.45 \pm 0.69$ & $1.39 \pm 0.26$ & $0.88 \pm 0.21$ & $1.66 \pm 0.46$ \\
\hline $\mathrm{CT} / \mathrm{TT}$ & 235 & $4.77 \pm 0.96$ & $1.02(0.80)$ & $1.87 \pm 0.50$ & $2.64 \pm 0.73$ & $1.40 \pm 0.25$ & $0.91 \pm 0.21$ & $1.61 \pm 0.44$ \\
\hline$F$ & - & 1.807 & 0.710 & 0.168 & 2.160 & 0.188 & 1.128 & 0.966 \\
\hline$P$ & - & 0.072 & 0.478 & 0.867 & 0.032 & 0.851 & 0.260 & 0.335 \\
\hline
\end{tabular}


Table 3: Genotypic frequencies of the MTHFR C677T and serum lipid levels between the Bai Ku Yao and Han populations (Continued)

\begin{tabular}{lllllllll} 
Female & & & & & & \\
CC & 117 & $4.55 \pm 0.76$ & $0.92(0.74)$ & $1.93 \pm 0.46$ & $2.50 \pm 0.61$ & $1.41 \pm 0.19$ & $0.87 \pm 0.19$ & $1.68 \pm 0.41$ \\
$C T$ & 188 & $4.81 \pm 1.02^{\mathrm{a}}$ & $1.00(0.76)$ & $1.98 \pm 0.45$ & $2.65 \pm 0.78$ & $1.44 \pm 0.24$ & $0.93 \pm 0.22$ & $1.63 \pm 0.42$ \\
$T$ & 39 & $4.80 \pm 0.72$ & $0.97(0.76)$ & $1.97 \pm 0.47$ & $2.64 \pm 0.62$ & $1.44 \pm 0.16$ & $0.91 \pm 0.19$ & $1.65 \pm 0.45$ \\
$F$ & - & 3.091 & 1.704 & 0.377 & 1.802 & 1.002 & 2.487 & 0.537 \\
$P$ & - & 0.047 & 0.427 & 0.687 & 0.167 & 0.368 & 0.085 & 0.585 \\
$C C$ & 117 & $4.55 \pm 0.76$ & $0.92(0.74)$ & $1.93 \pm 0.46$ & $2.50 \pm 0.61$ & $1.41 \pm 0.19$ & $0.87 \pm 0.19$ & $1.68 \pm 0.41$ \\
$C T / T T$ & 227 & $4.81 \pm 0.97$ & $1.00(0.76)$ & $1.98 \pm 0.45$ & $2.65 \pm 0.72$ & $1.44 \pm 0.23$ & $0.92 \pm 0.21$ & $1.63 \pm 0.42$ \\
$F$ & - & 2.489 & 1.288 & 0.864 & 1.892 & 1.400 & 2.191 & 0.979 \\
$P$ & - & 0.013 & 0.198 & 0.388 & 0.059 & 0.162 & 0.029 & 0.328 \\
\hline
\end{tabular}

TC, total cholesterol; TG, triglyceride; HDL-C, high-density lipoprotein cholesterol; LDL-C, low-density lipoprotein cholesterol; ApoAl, apolipoprotein Al; ApoB, apolipoprotein B; ApoAl/ApoB, the ratio of apolipoprotein Al to apolipoprotein B. The value of TG was presented as median (interquartile range). The difference in serum TG levels was determined by the Kruskal-Wallis test or the Wilcoxon-Mann-Whitney test. ${ }^{\mathrm{a}} P<0.05$ and ${ }^{\mathrm{b}} P<0.05$ in comparison with CC genotype and ${ }^{c} P<0.05$ in comparison with $C T$ genotype in the same group.

Table 4 Correlative factors for serum lipid paramerers between the Bai Ku Yao and Han populations

\begin{tabular}{|c|c|c|c|c|c|}
\hline Lipid & Relative factor & Regression coefficient & Standard error & $\chi^{2}$ & $P$ \\
\hline \multicolumn{6}{|c|}{ Bai Ku Yao and Han } \\
\hline \multirow[t]{5}{*}{$\mathrm{TC}$} & Sex & -0.732 & 0.156 & 21.958 & 0.000 \\
\hline & Age & 0.011 & 0.005 & 5.847 & 0.016 \\
\hline & Alcohol consumption & -0.627 & 0.110 & 32.569 & 0.000 \\
\hline & Ethnic group & 0.333 & 0.133 & 6.245 & 0.012 \\
\hline & Body mass index & 0.154 & 0.026 & 35.384 & 0.000 \\
\hline \multirow[t]{2}{*}{ TG } & Cigarette smoking & 0.322 & 0.108 & 8.865 & 0.003 \\
\hline & Genotype & 0.169 & 0.026 & 23.201 & 0.000 \\
\hline \multirow[t]{3}{*}{$\mathrm{HDL}-\mathrm{C}$} & Age & -0.035 & 0.014 & 6.392 & 0.011 \\
\hline & Cigarette smoking & 0.601 & 0.245 & 6.037 & 0.014 \\
\hline & Ethnic group & -1.043 & 0.365 & 8.106 & 0.004 \\
\hline \multirow[t]{4}{*}{$\mathrm{LDL}-\mathrm{C}$} & Age & 0.013 & 0.006 & 3.875 & 0.049 \\
\hline & Cigarette smoking & -1.070 & 0.178 & 36.257 & 0.000 \\
\hline & Alcohol consumption & -1.243 & 0.181 & 47.134 & 0.000 \\
\hline & Genotype & 0.164 & 0.034 & 23.437 & 0.000 \\
\hline \multirow[t]{3}{*}{ ApoAl } & Sex & 0.745 & 0.149 & 25.013 & 0.000 \\
\hline & Alcohol consumption & -0.272 & 0.094 & 8.320 & 0.004 \\
\hline & Ethnic group & -0.498 & 0.084 & 21.805 & 0.000 \\
\hline \multirow[t]{3}{*}{ ApoB } & Alcohol consumption & -0.573 & 0.089 & 31.968 & 0.000 \\
\hline & Ethnic group & -0.435 & 0.116 & 14.142 & 0.000 \\
\hline & Sex & 0.536 & 0.146 & 13.468 & 0.000 \\
\hline \multirow[t]{4}{*}{ ApoAl/ApoB } & Alcohol consumption & -0.250 & 0.089 & 7.973 & 0.005 \\
\hline & Ethnic group & 0.593 & 0.103 & 32.808 & 0.000 \\
\hline & Genotype & -0.117 & 0.024 & 24.545 & 0.000 \\
\hline & Systolic blood pressure & -0.265 & 0.096 & 7.650 & 0.006 \\
\hline \multicolumn{6}{|l|}{ Bai Ku Yao } \\
\hline \multirow[t]{3}{*}{$\mathrm{TC}$} & Sex & -4.320 & 0.567 & 57.972 & 0.000 \\
\hline & Alcohol consumption & -5.245 & 0.805 & 48.720 & 0.000 \\
\hline & Genotype & 1.160 & 0.249 & 21.732 & 0.000 \\
\hline \multirow[t]{3}{*}{ TG } & Sex & 0.693 & 0.259 & 7.155 & 0.007 \\
\hline & Body mass index & 0.180 & 0.039 & 21.249 & 0.000 \\
\hline & Genotype & 0.537 & 1.162 & 10.924 & 0.001 \\
\hline \multirow[t]{3}{*}{$\mathrm{HDL}-\mathrm{C}$} & Age & -0.031 & 0.010 & 4.119 & 0.047 \\
\hline & Cigarette smoking & 0.695 & 0.315 & 4.872 & 0.027 \\
\hline & Alcohol consumption & 0.859 & 0.294 & 8.545 & 0.003 \\
\hline
\end{tabular}


Table 4: Correlative factors for serum lipid paramerers between the Bai Ku Yao and Han populations (Continued)

\begin{tabular}{|c|c|c|c|c|c|}
\hline \multirow[t]{2}{*}{ LDL-C } & Age & 0.040 & 0.015 & 6.971 & 0.008 \\
\hline & Genotype & 0.357 & 0.156 & 5.244 & 0.022 \\
\hline \multirow[t]{3}{*}{ ApoAl } & Sex & 1.021 & 0.217 & 22.085 & 0.000 \\
\hline & Alcohol consumption & -0.869 & 0.145 & 35.851 & 0.000 \\
\hline & Body mass index & -0.121 & 0.038 & 10.306 & 0.001 \\
\hline \multirow[t]{3}{*}{ ApoB } & Sex & 0.781 & 0.253 & 9.557 & 0.002 \\
\hline & Alcohol consumption & -3.687 & 0.682 & 37.490 & 0.000 \\
\hline & Body mass index & -0.115 & 0.156 & 8.197 & 0.004 \\
\hline \multirow[t]{2}{*}{ ApoAl/ApoB } & Sex & 1.049 & 0.209 & 25.098 & 0.000 \\
\hline & Body mass index & -0.105 & 0.035 & 9.141 & 0.002 \\
\hline \multicolumn{6}{|l|}{ Han Chinese } \\
\hline \multirow[t]{2}{*}{ TC } & Age & 0.027 & 0.007 & 16.531 & 0.000 \\
\hline & Body mass index & 0.164 & 0.033 & 24.132 & 0.000 \\
\hline \multirow[t]{2}{*}{ TG } & Cigarette smoking & 0.380 & 0.140 & 7.338 & 0.007 \\
\hline & Body mass index & 0.232 & 0.037 & 38.897 & 0.000 \\
\hline $\mathrm{HDL}-\mathrm{C}$ & Age & -0.060 & 0.031 & 3.865 & 0.049 \\
\hline \multirow[t]{3}{*}{ LDL-C } & Age & 0.022 & 0.009 & 5.483 & 0.019 \\
\hline & Body mass index & 0.215 & 0.043 & 24.399 & 0.000 \\
\hline & Genotype & 0.503 & 0.133 & 14.276 & 0.000 \\
\hline ApoAl & Alcohol consumption & 0.333 & 0.125 & 7.033 & 0.008 \\
\hline ApoB & Body mass index & 0.067 & 0.030 & 5.087 & 0.024 \\
\hline \multirow[t]{3}{*}{ ApoAl/ApoB } & Age & -0.021 & 0.007 & 9.644 & 0.002 \\
\hline & Alcohol consumption & -0.355 & 0.123 & 8.280 & 0.004 \\
\hline & Body mass index & -0.124 & 0.033 & 14.076 & 0.000 \\
\hline
\end{tabular}

TC, total cholesterol; TG, triglyceride; HDL-C, high-density lipoprotein cholesterol; LDL-C, low-density lipoprotein cholesterol; ApoAl, apolipoprotein Al; ApoB, apolipoprotein B; ApoAl/ApoB, the ratio of apolipoprotein Al to apolipoprotein B.

two ethnic groups may relate to the difference in the MTHFR gene-enviromental interactions [12].

In the present study, we also found that several environmental factors affect serum lipid levels. Serum lipid parameters were correlated with age, sex, alcohol consumption, cigarette smoking, BMI, and blood pressure. These findings suggest that the environmental factors also play an important role in determining serum lipid levels in these populations $[7,8]$. There was significant difference in diet and lifestyle between the two ethnic groups. Corn was the staple food and rice, soy, buckwheat, sweet potato, and pumpkin products were the subsidiary foods in Bai $\mathrm{Ku}$ Yao. Approximately 90\% of the beverages were corn wine and rum. The alcohol content is about $15 \%(\mathrm{v} / \mathrm{v})$. They are also accustomed to drink Hempseed soup. In contrast, rice was the staple food and corn, broomcorn, potato, and taro products were the subsidiary foods in Han. About $90 \%$ of the beverage was rice wine. The content of alcohol is about $30 \%(\mathrm{v} / \mathrm{v})$. The staple and subsidiary foods are more favorable for serum lipid profiles in Bai $\mathrm{Ku}$ Yao than in Han. Corn contains abundant dietary fiber and plant protein [47]. Consumption of dietary fiber, specifically the soluble type, such as pectins and guar gum can decrease serum TC levels $[48,49]$. Plant protein might promote the transportation and excretion of free cholesterol. Dietary soy protein has well-documented beneficial effects on serum lipid concentrations [50,51]. Buckwheat protein product has a potent hypocholesterolemic activity [52,53]. Ludvik et al. [54] found that ingestion of $4 \mathrm{~g} /$ day caiapo (the extract of white-skinned sweet potato) for 6 weeks reduces TC and LDL-C in type 2 diabetic patients previously treated by diet alone. Studies have demonstrated that pumpkin is a useful therapy for hypercholesterolemia through reducing oxidative stress and cholesterol levels [55]. There are more than 29 fat soluble constituents in Hempseed, among which saturated and unsaturated fatty acid methyl esters account for $12.36 \%$ and $86.96 \%$; respectively $[56,57]$. Several experimental and clinical studies have demonstrated that Hempseed or Hempseed oil can decrease TC, TG and LDL-C levels, inhibit lipid peroxidation, and reduce atherogenic index [58-62].

\section{Conclusion}

The present study shows that there was significant difference in the genotypic and allelic frequencies of MTHFR C677T polymorphism between the Bai Ku Yao and Han populations. The frequency of MTHFR 677T allele and $\mathrm{CT}$ and TT genotypes was lower in Bai Ku Yao than in 
Han. The $\mathrm{T}$ allele carriers in both ethnic groups had higher serum TC and LDL-C levels as compared with the $\mathrm{T}$ allele noncarriers. The $\mathrm{T}$ allele carriers in Han had higher serum ApoB levels than the $\mathrm{T}$ allele noncarriers. Multivariate logistic regression analysis showed that the levels of TC, TG and LDL-C in Bai Ku Yao and LDL-C in Han were correlated with genotypes. The differences in serum TC, TG, LDL-C and ApoB levels between the two ethnic groups might partly result from different genotypic and allelic frequencies of the MTHFR C677T or different MTHFR gene-enviromental interactions.

\section{Acknowledgements}

This study was supported by the National Natural Science Foundation of China (No: 30660061)

\section{Author details}

'Department of Cardiology, Institute of Cardiovascular Diseases, the First Affiliated Hospital, Guangxi Medical University, 22 Shuangyong Road, Nanning 530021, Guangxi, China. ${ }^{2}$ Department of Pathophysiology, School of Premedical Sciences, Guangxi Medical University, Nanning 530021, Guangxi, China.

\section{Authors' contributions}

LZ participated in the design, undertook genotyping, and helped to draft the manuscript. RXY conceived the study, participated in the design, carried out the epidemiological survey, collected the samples, and drafted the manuscript. WYL, LM, DFW, LHHA, XJH and XLC collaborated to the genotyping. JZW and SLP carried out the epidemiological survey, collected the samples, and helped to carry out the genotyping. All authors read and approved the final manuscript.

\section{Competing interests}

The authors declare that they have no competing interests.

Received: 8 October 2010 Accepted: 27 October 2010

Published: 27 October 2010

\section{References}

1. Martin MJ, Hulley SB, Browner WS, Kuller LH, Wentworth D: Serum cholesterol, blood pressure and mortality: implications from a cohort of 361,662 men. Lancet 1986, 2:933-6.

2. Hokanson JE, Austin MA: Plasma triglyceride level is a risk factor for cardiovascular disease independent of high-density lipoprotein cholesterol level: a meta-analysis of population-based prospective studies. J Cardiovasc Risk 1996, 3:213-9.

3. März W, Scharnagl H, Winkler K, Tiran A, Nauck M, Boehm BO, Winkelmann BR: Low-density lipoprotein triglycerides associated with low-grade systemic inflammation, adhesion molecules, and angiographic coronary artery disease: the Ludwigshafen Risk and Cardiovascular Health study. Circulation 2004, 110:3068-74.

4. Kwiterovich PO Jr, Coresh J, Smith HH, Bachorik PS, Derby CA, Pearson TA: Comparison of the plasma levels of apolipoproteins B and A-1, and other risk factors in men and women with premature coronary artery disease. Am J Cardiol 1992, 69:1015-21.

5. Durrington PN, Hunt L, Ishola M, Kane J, Stephens WP: Serum apolipoproteins $\mathrm{Al}$ and $\mathrm{B}$ and lipoproteins in middle aged men with and without previous myocardial infarction. Br Heart J 1986, 56:206-12.

6. Boden WE: High-density lipoprotein cholesterol as an independent risk factor in cardiovascular disease: Assessing the data from Framingham to the Veterans Affairs High-Density Lipoprotein Intervention Trail. Am J Cardiol 2000, 86:19L-22L.

7. Ruixing Y, Qiming F, Dezhai Y, Shuquan L, Weixiong L, Shangling P, Hai W, Yongzhong Y, Feng $\mathrm{H}$, Shuming Q: Comparison of demography, diet, lifestyle, and serum lipid levels between the Guangxi Bai Ku Yao and Han populations. J Lipid Res 2007, 48:2673-81.
8. Ruixing $Y$, Jinzhen $W$, Yaoheng H, Jing T, Hai W, Muyan L, Yiyang L, Dongmei F, Hanjun Y, Yuming C: Associations of diet and lifestyle with hyperlipidemia for middle-aged and elderly persons among the Guangxi Bai Ku Yao and Han populations. J Am Diet Assoc 2008, 108:970-6.

9. Yijiang Z, Ruixing Y, Yiyang L, Yaju D, Shangling P, Weixiong L, Dezhai Y: Association of TaqIB polymorphism in the cholesteryl ester transfer protein gene with serum lipid levels in the Guangxi Hei Yi Zhuang and Han populations. J Investig Med 2008, 56:847-57.

10. Yaju D, Ruixing Y, Yiyang $L$, Yijiang Z, Weixiong L, Shangling P, Dezhai $Y$ : Polymorphism of the sterol regulatory element-binding protein-2 gene and its association with serum lipid levels in the Guangxi Hei Yi Zhuang and Han populations. Am J Med Sci 2009, 337:14-22.

11. Meng $L$, Ruixing $Y$, Yiyang $L$, Xingjiang $L$, Kela $L$, Wanying $L$, $L i n ~ Z$ Weixiong L, Dezhai Y, Shangling P: Association of LIPC -250G>A polymorphism and several environmental factors with serum lipid levels in the Guangxi Bai Ku Yao and Han populations. Lipids Health Dis 2010, 9:28.

12. Ruixing $Y$, Yiyang $L$, Meng $L$, Kela $L$, Xingiiang $L$, Lin $Z$, Wanying $L$, Jinzhen W, Dezhai Y, Weixiong L: Interactions of the apolipoprotein C-III $3238 \mathrm{C}>\mathrm{G}$ polymorphism and alcohol consumption on serum triglyceride levels. Lipids Health Dis 2010, 9:86.

13. Heller DA, de Faire U, Pedersen NL, Dahlén G, McClearn GE: Genetic and environmental influences on serum lipid levels in twins. $N$ Engl I Med 1993, 328:1150-6.

14. Steinmetz J, Boerwinkle E, Gueguen R, Visvikis S, Henny J, Siest G: Multivariate genetic analysis of high density lipoprotein particles. Atherosclerosis 1992, 92:219-27.

15. Pérusse L, Rice T, Després JP, Bergeron J, Province MA, Gagnon J, Leon AS, Rao DC, Skinner JS, Wilmore JH, Bouchard C: Familial resemblance of plasma lipids, lipoproteins and postheparin lipoprotein and hepatic lipases in the HERITAGE Family Study. Arterioscler Thromb Vasc Biol 1997, 17:3263-9.

16. Regland B, Blennow K, Germgard T, Koch-Schmidt AC, Gottfries CG: The role of the polymorphic genes apolipoprotein $\mathrm{E}$ and methylenetetrahydrofolate reductase in the development of dementia of the Alzheimer type. Dement Geriatr Cogn Disord 1999, 10:245-51.

17. Nishiyama M, Kato $Y$, Hashimoto M, Yukawa S, Omori K: Apolipoprotein $E_{\text {, }}$ methylenetetrahydrofolate reductase (MTHFR) mutation and the risk of senile dementia-an epidemiological study using the polymerase chain reaction (PCR) method. J Epidemiol 2000, 10:163-72.

18. Kawamoto R, Kohara K, Tabara Y, Miki T, Doi T, Tokunaga H, Konishi I: An association of 5,10-methylenetetrahydrofolate reductase (MTHFR) gene polymorphism and common carotid atherosclerosis. J Hum Genet 2001, 46:506-10.

19. Yilmaz H, Agachan B, Isbir T, Akoglu E: Is there additional effect of MTHFR C677T mutation on lipid abnormalities in renal allograft recipients? Transplant Proc 2003, 35:1390-2.

20. Pitsavos C, Panagiotakos D, Trichopoulou A, Chrysohoou C, Dedoussis G, Chloptsios Y, Choumerianou D, Stefanadis C: Interaction between Mediterranean diet and methylenetetrahydrofolate reductase C677T mutation on oxidized low density lipoprotein concentrations: the ATTICA study. Nutr Metab Cardiovasc Dis 2006, 16:91-9.

21. Huemer M, Vonblon K, Födinger M, Krumpholz R, Hubmann M, Ulmer $H$, Simma B: Total homocysteine, folate, and cobalamin, and their relation to genetic polymorphisms, lifestyle and body mass index in healthy children and adolescents. Pediatr Res 2006, 60:764-9.

22. Zuntar I, Antoljak N, Vrkić N, Topić E, Kujundzić N, Demarin V, Vuković V: Association of methylenetetrahydrofolate (MTHFR) and apolipoprotein $E$ (apo E) genotypes with homocysteine, vitamin and lipid levels in carotid stenosis. Coll Antropol 2006, 30:871-8.

23. Koubaa N, Nakbi A, Smaoui M, Abid N, Chaaba R, Abid M, Hammami M: Hyperhomocysteinemia and elevated ox-LDL in Tunisian type 2 diabetic patients: role of genetic and dietary factors. Clin Biochem 2007, 40:1007-14.

24. Huang L, Song $X M$, Zhu WL, Li Y: Plasma homocysteine and gene polymorphisms associated with the risk of hyperlipidemia in northern Chinese subjects. Biomed Environ Sci 2008, 21:514-20.

25. Real JT, Martinez-Hervas S, Garcia-Garcia AB, Chaves FJ, Civera M, Ascaso JF, Carmena R: Association of C677T polymorphism in MTHFR gene, high homocysteine and low HDL cholesterol plasma values in heterozygous familial hypercholesterolemia. J Atheroscler Thromb 2009, 16:815-20. 
26. Kerkeni M, Addad F, Chauffert M, Myara A, Gerhardt M, Chevenne D, Trivin F, Farhat MB, Miled A, Maaroufi K: Hyperhomocysteinaemia, methylenetetrahydrofolate reductase polymorphism and risk of coronary artery disease. Ann Clin Biochem 2006, 43:200-6.

27. Ou T, Yamakawa-Kobayashi $K$, Arinami T, Amemiya H, Fujiwara H, Kawata K, Saito M, Kikuchi S, Noguchi Y, Sugishita Y, Hamaguchi H: Methylenetetrahydrofolate reductase and apolipoprotein $E$ polymorphisms are independent risk factors for coronary heart disease in Japanese: a case-control study. Atherosclerosis 1998, 137:23-8.

28. Falchi A, Giovannoni L, Piras IS, Calo CM, Moral P, Vona G, Varesi L: Prevalence of genetic risk factors for coronary artery disease in Corsica island (France). Exp Mol Pathol 2005, 79:210-3.

29. Maitland-van der Zee AH, Lynch A, Boerwinkle E, Arnett DK, Davis BR, Leiendecker-Foster C, Ford CE, Eckfeldt JH: Interactions between the single nucleotide polymorphisms in the homocysteine pathway (MTHFR 677C >T, MTHFR $1298 \mathrm{~A}>\mathrm{C}$, and CBSins) and the efficacy of HMG-CoA reductase inhibitors in preventing cardiovascular disease in high-risk patients of hypertension: the GenHAT study. Pharmacogenet Genomics 2008, 18:651-6.

30. Rallidis LS, Gialeraki A, Komporozos C, Vavoulis P, Pavlakis G, Travlou A, Lekakis I, Kremastinos DT: Role of methylenetetrahydrofolate reductase 677C->T polymorphism in the development of premature myocardial infarction. Atherosclerosis 2008, 200:115-20.

31. Loktionov A, Vorster H, O'Neill IK, Nell T, Bingham SA, Runswick SA, Cummings $\mathrm{JH}$ : Apolipoprotein $\mathrm{E}$ and methylenetetrahydrofolate reductase genetic polymorphisms in relation to other risk factors for cardiovascular disease in UK Caucasians and Black South Africans. Atherosclerosis 1999, 145:125-35.

32. Gallistl S, Sudi K, Mangge H, Erwa W, Borkenstein M: Insulin is an independent correlate of plasma homocysteine levels in obese children and adolescents. Diabetes Care 2000, 23:1348-52.

33. Spiridonova MG, Stepanov VA, Pyzyrev VP, Karpov RS: Relationship between polymorphism C677T of the methylene tetrahydrofolate reductase gene with clinical symptoms of coronary atherosclerosis. Genetika 2000, 36:1269-73.

34. Rothenbacher D, Fischer HG, Hoffmeister A, Hoffmann MM, März W, Bode G, Rosenthal J, Koenig W, Brenner H: Homocysteine and methylenetetrahydrofolate reductase genotype: association with risk of coronary heart disease and relation to inflammatory, hemostatic, and lipid parameters. Atherosclerosis 2002, 162:193-200.

35. Helfenstein T, Fonseca FA, Relvas WG, Santos AO, Dabela ML, Matheus SC, D'Almeida V, Tufik S, Souza FG, Rodrigues PR, Taglieri R, Sousa EF, Izar MC: Prevalence of myocardial infarction is related to hyperhomocysteinemia but not influenced by C677T methylenetetrahydrofolate reductase and A2756G methionine synthase polymorphisms in diabetic and nondiabetic subjects. Clin Chim Acta 2005, 355:165-72.

36. Ibrahim S, El Dessokiy O: Prevalence of methylenetetrahydrofolate gene (MTHFR) C677T polymorphism among chronic hemodialysis patients and its association with cardiovascular disease: a cross-sectional analysis. Clin Exp Nephrol 2009, 13:501-7.

37. People's Republic of China-United States Cardiovascular and Cardiopulmonary Epidemiology Research Group: An epidemiological study of cardiovascular and cardiopulmonary disease risk factors in four populations in the People's Republic of China. Baseline report from the P.R.C.-U.S.A. Collaborative Study. Circulation 1992, 85:1083-96.

38. Pan Q, Guo LX, Chu MF, Man Y, Sun MX, Li M, Liu XP: Relationship between genetic polymorphisms of homocysteine metablism related enzymes and carotid intima-media thickness in type 2 diabetic patients. Chin J Arterioscler 2005, 13:195-8.

39. Xing XR, Hua Q, Zhang Z, Liu RK: The relationships between methylenetetrahydrofolate reductase gene C677T polymorphism and arterial compliance in patients with essential hypertension. Chin J Arterioscler 2006, 14:979-81.

40. Xing XR, Hua Q: Relationships between the polymorphism of methylenetetrahydrofolate reductase gene C677T and hypertension, cardiac structure and function. Med J Chin PLA 2007, 32:741-4.

41. Ruixing $Y$, Weixiong $L$, Hanjun $Y$, Dezhai $Y$, Shuquan $L$, Shangling $P$, Qiming F, Jinzhen W, Jianting G, Yaju D: Diet, lifestyle, and blood pressure of the middle-aged and elderly in the Guangxi Bai Ku Yao and Han populations. Am J Hypertens 2008, 21:382-7.

42. Ruixing $Y$, Shangling $P$, Shuquan $L$, Dezhai $Y$, Weixiong L, Qiming F, Yuming C, Yaoheng $H$, Yijiang Z, Qinchen $L$ : Comparison of hypertension and its risk factors between the Guangxi Bai Ku Yao and Han populations. Blood Press 2008, 17:306-16.

43. Cooperative Meta-analysis Group of China Obesity Task Force: Predictive values of body mass index and waist circumference to risk factors of related diseases in Chinese adult population. Chin J Epidemiol 2002, 23:5-10.

44. Cortese C, Motti C: MTHFR gene polymorphism, homocysteine and cardiovascular disease. Public Health Nutr 2001, 4:493-7.

45. Al-Muhanna F, Al-Mueilo S, Al-Ali A, Larbi E, Rubaish A, Abdulmohsen MF, Al-Zahrani A, Al-Ateeq S: Polymorphism in methylenetetrahydrofolate reductase, plasminogen activator inhibitor-1, and apolipoprotein $E$ in hemodialysis patients. Saudi J Kidney Dis Transp/ 2008, 19:937-41.

46. Nakai K, Habano W, Nakai K, Fukushima N, Fujita T, Gurwitz D: Ethnic differences of coronary artery disease-associated SNPs in two Israeli healthy populations using MALDI-TOF mass spectrometry. Life Sci 2004, 75:1003-10.

47. Dong W, Ma X, Zhang D, Yu S: Effect of maize embryo on delaying aging Food Sci 2002, 23:95-7.

48. Jenkins DJ, Kendall CW, Axelsen M, Augustin LS, Vusksan V: Viscous and nonviscous fibres, nonabsorbable and low glycaemic index carbohydrates, blood lipids and coronary heart disease. Curr Opin Lipidol 2000, 11:49-56.

49. Lairon D: Dietary fibres: effects on lipid metabolism and mechanisms of action. Eur J Clin Nutr 1996, 50:125-33.

50. Weggemans RM, Trautwein EA: Relation between soy-associated isoflavones and LDL and HDL cholesterol concentrations in humans: a meta-analysis. Eur J Clin Nutr 2003, 57:940-6.

51. Zhan S, Ho SC: Meta-analysis of the effects of soy protein containing isoflavones on the lipid profile. Am J Clin Nutr 2005, 81:397-408.

52. Tomotake H, Shimaoka I, Kayashita J, Yokoyama F, Nakajoh M, Kato N: Stronger suppression of plasma cholesterol and enhancement of the fecal excretion of steroids by a buckwheat protein product than by a soy protein isolate in rats fed on a cholesterol-free diet. Biosci Biotechnol Biochem 2001, 65:1412-4.

53. Kayashita J, Shimaoka I, Nakajoh M, Yamazaki M, Kato N: Consumption of buckwheat protein lowers plasma cholesterol and raises fecal neutral sterols in cholesterol-Fed rats because of its low digestibility. J Nutr 1997, 127:1395-400.

54. Ludvik BH, Mahdjoobian K, Waldhaeusl W, Hofer A, Prager R, KautzkyWiller A, Pacini G: The effect of Ipomoea batatas (Caiapo) on glucose metabolism and serum cholesterol in patients with type 2 diabetes: a randomized study. Diabetes Care 2002, 25:239-40.

55. Adaramoye OA, Achem J, Akintayo OO, Fafunso MA: Hypolipidemic effect of Telfairia occidentalis (fluted pumpkin) in rats fed a cholesterol-rich diet. J Med Food 2007, 10:330-6.

56. Zhang Y, Wang ZZ: GC-MS analysis of fat-soluble constituents of Hemp Kernels. Acta Bot Boreal - Occident Sin 2006, 26:1955-8.

57. Ross SA, Mehmedic Z, Murphy TP, Elsohly MA: GC-MS analysis of the total delta9-THC content of both drug- and fiber-type cannabis seeds. J Anal Toxicol 2000, 24:715-7.

58. Cen L, Qin W, Ye Y: Effect of Canabis Sativa $L$ on serum cholesterol level in rats. J Guangxi Med Univ 1984, 1:20-2.

59. Qin W, Cen L, Ye Y: The effect of some foods on serum cholesterol level in rats. Acta Nutrimenta Sinica 1986, 8:136-40.

60. Ren HY, Sun HG, Ma JZ, Zhang Y, Yi CR, Wu MX, Liu WL, Li GL: Experimental study on the effects of: hemp fruit oil on serun lipid levels and lipid peroxidation. Chin J Tradit Med Sci Technol 1997, 4:200.

61. Ren HY, Sun HG, Zhang Y, Yi CR, Wu MX, Li GL, Liu WL: Lipid-lowering and antiatherosclerotic effects of hemp fruit oil in partridges. Henan Tradit Chin Med 1998, 18:294-5.

62. Schwab US, Callaway J, Erkkila AT, Gynther J, Uusitupa MI, Jarvinen T: Effects of hempseed and flaxseed oils on the profile of serum lipids, serum total and lipoprotein lipid concentrations and haemostatic factors. Eur J Nutr 2006, 45:470-7.

doi:10.1186/1476-511X-9-123

Cite this article as: Zhang et al:: Association of methylenetetrahydrofolate reductase C677T polymorphism and serum lipid levels in the Guangxi Bai Ku Yao and Han populations. Lipids in Health and Disease 2010 9:123. 